\title{
Development Education and Global Learning: Lessons from Educationists in the Global South- Members of GPENreformation ${ }^{1}$
}

\begin{abstract}
The celebration of the $500^{\text {th }}$ Protestant Reformation Jubilee in 2017 has boosted the creation of an international network of Protestant institutions named GPENreformation, which currently brings together more than 46,000 schools and universities from all over the world of which more than half the members are from the African continent. These institutions join in different educational activities which allow the sharing of experiences through, for instance, short or long-term global learning projects. The article explores lessons learnt by protestant educationists in the Global South members of GPENreformation through a qualitative approach using semistructured interviews and thematic content analysis. The findings indicate that participants find the network as an open space and dialogue among schools in the Global South and North. Moreover, the network has contributed to the change of perspectives from a closer nationalism to more open international perspectives. The GPENreformation has likewise engineered the regional networks contributing to actions and reflections of peace and values in the Global South. However, inequality of school resources and asymmetric understanding of partnerships should be reflected in the GPENreformation.
\end{abstract}

Keywords: development education, global learning, educational quality, school networks

\section{Zusammenfassung}

Im Jahr 2017 hat die Jubiläumsfeier „500 Jahre Reformation“ die Gründung eines internationalen Netzwerks protestantischer Einrichtungen unter dem Namen GPENreformation vorangetrieben. Dieses Netzwerk umfasst derzeitig mehr als 46.000 Schulen und Universitäten aus der ganzen Welt, von denen mehr als die Hälfte dem afrikanischen Kontinent angehören. Diese Einrichtungen beteiligen sich an verschiedenen Bildungsaktivitäten, die einen Erfahrungsaustausch - z. B. über kurz- oder langfristige globale Lernprojekte ${ }^{2}$ - ermöglichen. Der Artikel nimmt die Anregungen in den Blick, die protestantische Pädagog/-innen im Globalen Süden aus
GPENreformation mitgenommen haben: Methodisch wurde mit einem qualitativen Forschungsansatz mit Hilfe halbstrukturierter Interviews und Inhaltsanalyse gearbeitet. Die Ergebnisse zeigen, dass die Teilnehmenden das Netzwerk als einen offenen Raum und Dialog zwischen Schulen im globalen Süden und Norden spezifizieren. Zudem hat das Netzwerk zum Perspektivenwechsel von einem engeren Nationenbezug zu offeneren internationalen Perspektiven beigetragen. Die GPENreformation hat sich darüber hinaus auch auf die Gestaltung regionaler Netzwerke ausgewirkt, die zur friedensbildenden Aktionen und Wertebildung im globalen Süden beitragen. Jedoch sollten die Ungleichheit der schulischen Ressourcen und ein asymmetrisches Verständnis von Partnerschaften im Kontext von GPENreformation reflektiert werden.

Schlüsselworte: Entwicklungspädagogik, Globales Lernen, Bildungsungleichheit, Bildungsqualität, Schulznetzwerke

\section{Introduction}

Research shows that education plays a fundamental role in sustainable development both at national and global level (Engjellushe, 2013, p. 228; Little, 2009, p.172-174; Hopkins \& McKeown, 2002, p. 13). "The link between education and sustainable development is strong. The theory of the future for sustainable development may not receive or find the application, development and widespread support if people are not educated and do not receive adequate information." (Engjellushe, 2013, p. 231). Education networks are seen as one of the stimulating factors for ensuring high-quality schools' development (Sliwka, 2003, p. 63). This is supported by the fact that education is closely linked to development, as well as sustainable development. It appears that the world population has to cooperate to ensure a sustainable future which requires contribution of everyone (UNESCO, 2016). This kind of collaboration is particularly sought after in the education sector so that young generations may acquire the desired competences. This is because "sustainable development necessitates well trained people able to make the appropriate decisions." (Pigozzi, 2007, p. 27) 
This article focuses on GPENreformation - an international network of Protestant institutions created in 2017 for the celebration of the 500th Protestant Reformation Jubilee in 2017. For the moment, the network brings together 866 schools and universities from all over the world. More than half are from the African continent as single institutions with more than 46,000 schools being indirect members by the membership of their umbrella associations. These schools join in different educational activities allowing the sharing of experiences through, for instance, short or long-term global learning projects. As a recent network, no research has been yet conducted to assess the contribution of this network in regard to education quality, especially for member schools located in the Global South. This paper is the first empirical contribution on the relationship between educational quality, sustainable development and this school network. The study was guided by the following research questions: How does being a member of GPENreformation as a Protestant school from the Global South contribute to the development of its educational quality? What do educationists learn through being members of GPENreformation? And how do they make use of what they learnt in developing their education quality? Two countries, namely the Democratic Republic of Congo and Rwanda, where churches play an important role in education, have been chosen. In Rwanda almost $60 \%$ of schools (from nursery to secondary) belong to churches (Republic of Rwanda, 2019) and in the Democratic Republic of Congo (DRC) more than $70 \%$ (Boak \& Smith, 2009, p. 5).

\section{Development Education and Global Learning: Conceptual Perspectives}

Different names have been associated with development education. These terms include "education for development, global education, global citizenship, themes such as global dimension in education, or more recently global learning" (Bourn, 2012, p. 25). When the concept of development education emerged in the late 1960s and 1970s, it was mainly connected to the growth of development, aid organisations and decolonisation (Bourn, 2008, p. 6). However, global education brought another perspective of viewing development as a shared challenge for both developing and developed countries (Scheunpflug $\&$ Asbrand, 2006, p. 36).

At the beginning of the 21 st century, educationalists launched a debate that led to the intensive use of terms of global learning, global citizenship education, and global dimension. Here, Scheunpflug suggested avoiding the distinction between the Global North and the Global South, but instead focusing on a global society striving for social justice (Hartmeyer, 2008 as cited in Bourn, 2014, p. 11). According to Scheunpflug, the aim of global learning should be to provide learning opportunities and offer learners opportunities to participate actively and responsibly in the dynamics of the world society. In order to accomplish this, teachers should have sufficient knowledge about global issues, and use this knowledge in the classroom. In the same line, Bourn underlines that "development education should be seen as a learning process rather than as a fixed and finite concept with specific goals and outcomes. It should provide a pedagogical framework for im- plementing global learning in schools" (2014, p. 12). To achieve this learning process, Bourn supports the idea of exposing learners to various learning opportunities including use of different teaching approaches, sharing of experiences, as well as further learning and study in order to actively engage learners to establish connections, to think critically, to reflect about overarching issues and to see themselves as global citizens (ibid. 2014, p. 15).

Networking is indicated to be one of the elements with potential for introducing global education in schools (ET2020 Working Group Schools, 2018; Wohlstetter, Malloy, Chau \& Polhenus, 2003). According to Sliwka (2003), networking in education has been in existence for a long time, but became popular at the beginning of the 21 st century. Educational networks offer opportunities for professional capacity building through learning from others about good practice and expertise. Education networks may be classified in terms of size and geographical scope (regional, national, and international), or the kind of addressed members. Education networks can be either open or closed. In most cases, education networks are comprised of multifaceted educational stakeholders, that is to say, providing a platform for students, teachers, schools leaders, schools, universities, research institutes, policy makers, etc. For ensuring effective and sustainable schools' networking, four elements are identified. These elements are purpose and motivation, collaborative network activity and network structures, members and their roles. The central and coordinating element is network leadership. Given that networks are subjected to change depending on a number of factors including time, this should also be considered (Stott, Jopling, \& Kilcher, 2006, p. 4). Members of a network should engage in various activities including allowing people from different schools to meet and have dialogue for getting to know one another and work together, to establish connections, share information across schools, and organize occasions for capacity building either as individuals or in groups (ibid., p. 13).

Besides Annette Scheunpflug, Vanessa Andreotti is another scholar whose contribution influenced the change of perspective about development education. Andreotti emphasizes critical engagement as a possibility for participants to come up with a mutual understanding about global issues (Andreotti, Barker \& Newell-Jones 2006, p. 4). Andreotti argues that learners need to be given opportunities to construct their identities and compare with other social groups by writing, and re-writing. Allowing learners to see the difference among social groups as a source of learning and an opportunity and by this value their own identities (Andreotti $\&$ de Souza, 2008, pp. 27-28).

In nutshell, three perspectives of global learning may be summarized. First, the shift from nationalism to cosmopolitanism. This means that global education facilitates the process of global citizenship (see Scheunpflug, 2010 and Bourn, 2008 $\&$ 2014). Second, the importance of open spaces for dialogue for learning where education stakeholders actively and responsibly learn from one another in a form of networking (see Bourn 2014; Andreotti, 2010 and Sliwka, 2003). Third, the perspective of contextualization of global networking by reflecting local realities without compromising global issues (Bourn, 2008). 


\section{Methodology}

In this study, an explorative qualitative approach through interviews was used (Savin-Baden, 2013). In total, four interviews have been conducted with different educationists all of them having expertise in the field of education and working and/or leading educational institutions members of GPENreformation. The interviewees come from Rwanda and the Democratic Republic of Congo, especially in the Kivu Region. They have various experiences in education and all work with protestant schools. The identified interviewees were contacted and the four agreed to do interviews either by Skype or phone calls. Interviews were transcribed and analysed using thematic content analysis. With respect to ethical considerations (Savin-Baden, 2013 \& DiCicco-Bloom \& Crabtree, 2006), interviewees are given pseudo-names $\mathrm{A}, \mathrm{B}, \mathrm{C}$ and $\mathrm{D}$.

\section{Findings}

The study at hand seeks to explore what educationalists in the Global South learn from being a member of GPENreformation and how the latter contributes to educational quality in the perspectives of development education and global learning. The findings from interviewees are presented under three themes: GPENreformation as an open platform for member schools, implications of GPENreformation to schools in the Global South and challenges for such a network.

\section{GPENreformation as Open Platform for Protes- tant Schools}

Interviewees feel proud of being members of GPENreformation. The major reason as mentioned by participants is that it is an open platform for networking protestant schools across the world. They indicate that the platform has been serving as a forum for exchanges and sharing of experiences between students, teachers and school administrators within schools in the network (A: 42-43 \& B: 368-374). The platform, as indicated by interviewees, offers opportunities for international exposure and networks as well as openness to others through sharing understandings and views.

First, participants in this study show that GPENreformation has offered opportunities for learning to live together and sharing life experiences. On the one hand, they indicated that, through youth camps and rotational mutual gatherings, they learnt to overcome stereotypes and break the barriers of mutual exclusion. For example, A expresses this as follows:

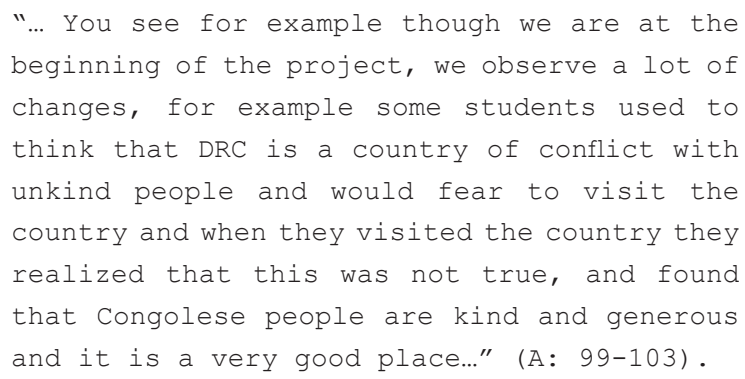

Additionally, participants indicate that youth camps as organized in Germany (2017) contributed to learning to live together especially interculturality through exchanges during the camps but also staying within families abroad. Furthermore, the platform has served as a tool for sharing hard times especially during the lockdown and closure of schools due to COVID-19. Interviewees indicates that it has been comforting to share conditions and effects of COVID-19 in different parts of the world, sharing experiences about continuity of teaching and learning as well as sharing messages of hope (B: 323-327; D: 254-277).

Secondly, participants show that being a member of GPENreformation offers paths for openness to the world. They indicate that it has been an opportunity for sharing views and understanding on annually provided themes. Moreover, the network, they express, serves as a platform for learning from others in schools all over the world, which later would stimulate self-reflection especially on the side of teachers as far as content and teaching approaches are concerned. GPENreformation offers students in the Global South international exposure by participating in internationally organized writing and artistic competitions where students in member schools reflect on one topic across the world. Participants indicate that schools may get information from different parts of the world via the GPENreformation website on which members post their experiences (A: 136-140).

\section{Implications of GPENreformation to Schools in the Global South}

Results from interviews show that GPENreformation has implications for schools in four perspectives: Protestant education, regional initiatives, quality education and driving individual networks and school partnerships both South-South and South-North.

Enlarging knowledge of values guiding protestant education: Participants in this study reveal that the relationship between quality education and the protestant faith was unknown to a number of students, teachers and leaders in protestant schools. In this framework, GPENreformation has been an opportunity to learn principles and values of protestant education, especially being driven by quality education and an insistence on autonomy, responsibility, inclusiveness and equity (A: 50-56; B: 238-239; C: 194-208 \& D: 242-250). The networking has not only served as an opportunity to learn protestant education related principles and values but their integration in protestant schools' daily practices: teaching and school leadership for example (A: 52-56). In addition, the network has encouraged unity among protestant schools by setting a shared profile of protestant schools worldwide (B: 238-254) which should be reflected in different contexts.

Regional initiatives: In addition to profiling and learning about protestant education, participants (A, B \& C) indicate that GPENreformation has driven regional initiatives. Participants narrate a joint programme for promotion of protestant values and peace education in the Great Lakes Region. The programme combines protestant schools in Rwanda, North and South East of DRC. The project was initiated as a response to the situation of ethnic, cross-boarders' conflicts and post-genocide situation which led to ill relationships within and between people in the region. The programme is being 
implemented through the development of modules on values of protestant education and peace education, rotational gatherings of students, teachers and educational leaders in the region. Participants indicate that the programme led to the creation of peace clubs in participating schools and houses of listening (C: 208-219). Through rotational gatherings, interviewees emphasize that this project has been leading to overcoming stereotypes among participants from different regions especially Rwanda and East DRC (A: 99-103). The biased and mutual misunderstanding was challenged by living together and sharing experiences. At the level of participating schools, peace clubs were created in order to regularly reflect peace related issues at national and regional levels as well as intervening in positively managing emerging conflicts within schools. Moreover, a house of listening was initiated by teachers in participating schools of North and South East of the DRC in order to provide counselling to emotionally affected students in schools, and this is seen as an important contribution from GPENreformation (C: 227-234).

Implication for educational quality in the Global South: As far as quality education is concerned, results show three main areas of a change of perspectives in regard to purpose and approach of education, education for global citizenship and joint initiatives with the purpose of improving educational quality. Firstly, results reveal a change of perspectives on the side of teachers and school leadership. For example, A expresses this as follows:

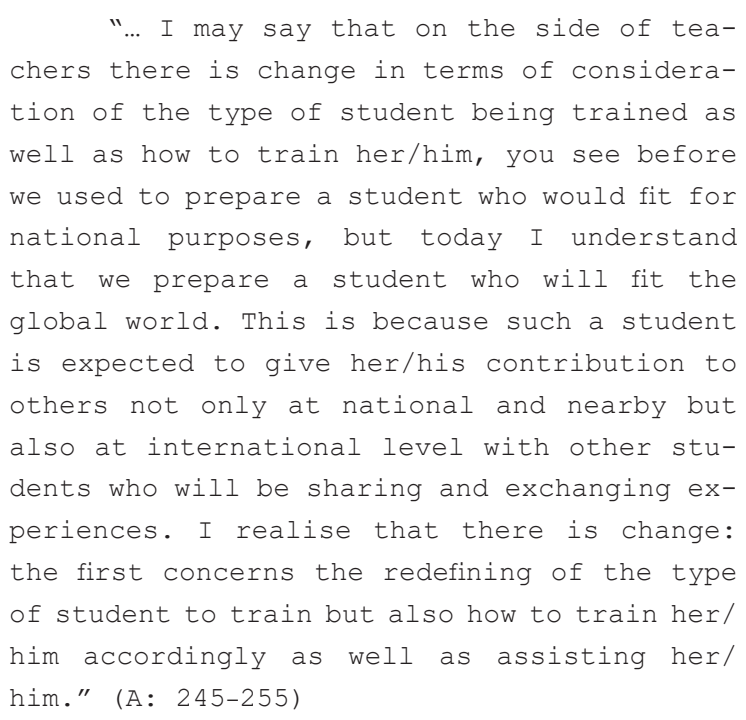

This excerpt shows that GPENreformation has contributed to the redefinition of the purpose and approach of education by moving from a nationalistic to a global orientation. Additionally, this shift is accompanied by a change of teaching approach whereby a teacher should reflect teaching approaches that would facilitate this. In this orientation, a learner-centred approach is seen as tool for giving a student a worldwide perspective (A: 270-276). As far as school leadership is concerned, GPENreformation has contributed to the process of rethinking and redefining the vision and mission of education especially the integration of not only values of protestant education but also progressive lessons from other fellow school leaders worldwide (A: 236-240). Moreover, by participating in internation- ally organized competitions, students' self-confidence and later participation in their own learning has been improved. Secondly and to supplement the first point, results show a change of perspective in terms of global citizens whereby teachers understand that students should be trained not only for national but also for international agendas so as to serve as global citizens. Through GPENreformation, interviewees reveal that students learn diversity of ideas and a capacity to tolerate different views as well as understanding the necessity of interdependence and complementarity of ideas in an open world (A: 168-172). Another important aspect is that students are considered as responsible citizens who do not only accept what they are told but have the critical thinking abilities to question what is being done at regional, national and international levels, especially risks and enabling factors for peace. In this perspective, participants indicate that they are given opportunities to reflect on causes of conflicts and wars at regional and international levels as future peace builders (B: 191-209 \& C: 256-264). Thirdly, GPENreformation has been a platform of not only sharing experiences but a forum for supporting one another among member schools with the purpose of improving educational quality and widening access to quality education for all especially vulnerable students. For example, one participant indicated that, through the network, one of the member school was supported to find school materials for vulnerable students. After being posted on the GPENreformation website, individuals and schools contributed and the problem was solved. Another example is one school which was built in Rwanda thanks to collaboration between protestant educational institutions in the Global South and protestant schools in the Global North (B: 390-410).

GPENreformation driving individual and schools' partnerships: The protestant schools' network-GPENreformation has been a driving force in developing interpersonal networks and school partnerships. Participants indicate that international camps, rotational gatherings in the Great Lakes Region as well as platforms offering the possibility of sharing experiences between schools via the GPENreformation website has significantly contributed to individual networks. Students, teachers, and school leaders are able to be in contact with peers worldwide through the exchange of experiences or sharing information (B: 366-373). Additionally, thanks to GPENreformation and related regional initiatives, partnerships between schools have been created. For example, partnerships among schools in the Global South: Rwanda, South and North Kivu in the DRC have created and enhanced the framework for promoting protestant education values and peace education (A: 352-354 \& C: 163-171). Moreover, interviewees show the development of partnerships between schools within one country. The example is the case of protestant schools in the South and North East Kivu in the DRC which organize regular mutual visits in order to share experiences. For example, teachers from South Kivu visited schools in North Kivu and learned the importance of counselling in schools through what it is named "maison d'écoute" (House of Listening). In this practice, both students and teachers are regularly offered counselling services on social and psychological issues likely to negatively affect teaching and learning especially in the conflict situation. As mentioned by $\mathrm{C}$, those teachers borrowed the same practice and initiated it 
in their own schools (196-245). Thanks to GPENreformation, partnerships between schools were initiated not only SouthSouth but also South-North. For example, one interviewee indicates that three schools in the Southern Province of Kivu in the DRC have initiated partnerships with schools in the Global North and mutual visits have already started (C: 162-184).

\section{Challenges}

Despite the positive implications of GPENreformation for schools in the Global South, participants indicate three major challenges likely to weaken such a network. They include limited familiarity with information and communication technology (ICT), language barriers and financial shortages. The first challenge is related to the use of ICT whereby some members (students, teachers, and school leaders), though registered as members of the network, remain inactive. One reason indicated by participants is limited ICT skills (A: 302-303). A second challenge is language. This is related to the fact that some members are not familiar with languages used in the network and the use of local language limits communication with others (A: 314-319). Financial shortage is another challenge. For example, one participant revealed that some schools especially in the Global South, due to financial constraint, expect to get financial support via the network in order to solve problems: old infrastructure, paying teachers. Unfortunately, as the network does not provide such support, they get discouraged because their expectations are not met (B: 266-302).

\section{Discussion}

The findings of this study are framed in four perspectives. First, the GPENreformation has been a platform for participating protestant schools worldwide. Second, the network has changed the understanding of purpose and practice of education especially from a nationalistic orientation to global education citizenship. Third, it has been an opportunity for local and regional partnership initiatives with the aims of contributing to the solution of problems in post-conflict societies. Fourth, challenges, there are asymmetric expectations where some participants anticipate themselves to be recipients of funding in the network.

The findings show that members who participated in this study view GPENreformation as an important platform for sharing experiences as far as educational quality improvement is concerned. Previous educational discourse on development education and global learning indicate that school networks should offer open spaces for dialogue: teacher-teacher collaboration and students' active participation (at class level, and on the platform) (see Bourn 2014; Andreotti \& de Souza, 2008; and Sliwka, 2003).

Moreover, participating in such a network has engineered changes of perspectives concerning the purpose and practice of teaching as well as the type of student to be trained. In this framework, the network has driven the change from nationalistic perspective to one of global citizenship in order to prepare a student who would fit in internationally. This shows that the network contributes to moving from nationalism to cosmopolitanism, from national to global citizen (Scheunpflug, 2010 and Bourn, 2008 \& 2014) which is important for preparing students for a globalized world.

Further to this latter point, the network has been an opportunity to initiate local, regional and international partnerships between schools both South-South and South-North. This means that GPENreformation has not only stayed at the international level but also reached the regional level in order to contribute to solve problems in the South. This is in line with Bourn (2008) who argues that global networks become effective when they reach the level of being contextualized at local and regional levels.

The findings likewise indicate challenges, which should be reflected in the perspective of improving the win-win partnerships. These include limited skills and access to ICT, language and financial support oriented expectations. This means that if it is not reflected, GPENreformation might enhance a traditional perspective of development education where participants in the Global South are considered as receivers and donors from the side of the Global North (Bourn, 2008).

\section{Conclusion and Implications}

The study at hand intended to explore lessons learnt by educationists in the Global South members of GPENreformation through a qualitative approach using semi-structured interviews and thematic content analysis. The findings indicate that participants find the network an open space and opportunity for dialogue among schools in the Global South and North. Moreover, the network has contributed to the change of perspectives from nation based education to international perspectives. The GPENreformation has likewise engineered the regional networks contribution to actions and reflections of peace and values in the Global South. However, inequality of school resources and an asymmetric understanding of partnerships might be reflected in the GPENreformation.

Basing on the findings, further studies should be conducted in the Global North in order to understand how participating school members view such a network. Moreover, there is need for ethnographic research in order to explore how GPENreformation member schools integrate what they learn from the network on both policy and practice. Furthermore, there is need for capacity building of members in order to understand the purposes of the network. This would make the network function in a win-win orientation.

\section{Notes}

1 GPENreformation: means Global Pedagogical Network - Joining in Reformation; https://www.gpenreformation.net/

2 https://www.gpenreformation.net/

\section{References}

Andreotti, V., Barker, L., \& Newell-Jones, K. (2006). Critical literacy in global citizenship education. Professional Development Resource Pack.

Andreotti, V., \& Souza, L. M. de (2008). Translating theory into practice and walking minefields: Lessons from the project "Through Other Eyes". International journal of development education and global learning, 1(1), 23-36. https://doi.org/10.1 8546/IJDEGL.01.1.03 
Boak, E., \& Smith, H. (2009). Study on Governance Challenges for Education in Fragile Situations. Democratic Republic of Congo Country Report. Euro-Trends. Zugriff am 26.11.2020 https://inee.org/system/files/resources/Country_Report_-_D RC.pdf

Bourn, D. (2008). Development Education: Towards a re-conceptualisation. International Journal of Development Education and Global Learning, 1(1), 5-22. https:// doi.org/10.18546/IJDEGL.01.1.02

Bourn, D. (2012). Development education: From the margins to the mainstream. The International Journal for Global and Development Education Research, (1), 25-39.

Bourn, D. (2014). The theory and practice of global learning. London: Development Education Research Centre, Institute of Education \& Global Learning Programme.

Bourn, D. (2015). From development education to global learning: Changing agendas and priorities. Policy \& Practice - A Development Education Review, 20, 18-36.

DiCicco-Bloom, B., \& Crabtree, B. F. (2006). The qualitative research interview. Medical education, 40(4), 314-321. https://doi.org/10.1111/j.1365-2929.2006.02 418.x

Engjellushe, E. (2013). Education for sustainable development. European journal of sustainable development, 2(4), 227-232. https://doi.org/10.14207/ejsd.2013.v2n $4 \mathrm{p} 227$

ET2020 Working Group Schools (2018). Networks for learning and development across school education: Guiding principles for policy development on the use of networks in school education systems. Brüssel: European Commission.

Hopkins, C., \& McKeown, R. (2002). Education for sustainable development: an international perspective. In D. Tilbury, R. B. Stevenson, J. Fien \& D. Schreuder (eds.), Education and sustainability: Responding to the global challenge (pp. 13-24). Gland \& Cambridge: Commission on Education and Communication, IUCN.

Little, A. W., \& Green, A. (2009). Successful globalisation, education and sustainable development. International Journal of Educational Development, 29(2), 166-174. https://doi.org/10.1016/j.ijedudev.2008.09.011

Pigozzi, M. J. (2007). Quality in education defines ESD. Journal of Education for Sustainable Development, 1(1), 27-35. https://doi.org/10.1177/09734082070010 0108

Republic of Rwanda (2019). 2019 Education statistics. Kigali: Ministry of Education.

Savin-Baden, M. \& Major, H. C. (2013). Qualitative research: The essential guide to theory and practice. New York: Routledge.

Scheunpflug, A. (2010). Global education and cross-cultural learning: A challenge for a research-based approach to international teacher education. International Journal of Development Education and Global Learning, 3(3), 29-44. https://doi.or g/10.18546/IJDEGL.03.3.03
Scheunpflug, A., \& Asbrand, B. (2006). Global education and education for sustainability. Environmental Education Research, 12(1),33-46. https://doi.org/10.1080/13 504620500526446

Schleicher, A. (2012). Preparing teachers and developing school leaders for the 21st century: Lessons from around the world. Paris: OECD. https://doi.org/10.1787/9 789264174559-en

Sliwka, A. (2003). Networking for educational innovation: A comparative analysis. Schooling for tomorrow. Networks of innovation, towards new models for managing schools and school systems, Paris: OECD, 49-63.

Stott, A., Jopling, M., \& Kilcher, A. (2006). How do school-to-school networks work? Nottingham: NCSL.

\section{Christine Nyiramana}

works as researcher and lecturer in teacher education at Protestant Institute of Arts and Social Sciences (PIASS), Rwanda. She is also the chair of the Board of Directors for PIASS - Centre for Didactics and Research in Education (CEDRE) and the coordinator of the International Master Programme in Educational Quality (IMPEQ) run in cooperation between the University Bamberg, Germany and three African universities, including PIASS. She is doing her doctoral studies in Educational Sciences at University of Bamberg. Her research interest is in teacher education, and educational quality.

\section{Emmanuel Niyibizi}

is a researcher, teacher educator and Director of the Centre for Didactics and Research in Education (CEDRE) at Protestant Institute of Arts and Social Sciences (PIASS), Rwanda. Currently, he is doing his $\mathrm{PhD}$ in foundations of education at the University of Bamberg-Bamberg Graduate School of Social Sciences (BAGSS), Germany. His PhD thesis focuses on "Teacher educators' subjective theories about quality teaching in Rwanda". His research interests include educational quality, teacher education, teaching; inclusive education and teacher professionalization. 